\title{
EGFR NP_005219.2:p.D770_N771insSVP
}

National Cancer Institute

\section{Source}

National Cancer Institute. EGFR NP 005219.2:p.D770 N771insSVP. NCI Thesaurus.

Code $C 98666$.

An insertion of the amino acid sequence serine-valine-proline between the aspartic acid at position 770 and the asparagine at position 771 of the epidermal growth factor receptor protein. 